\title{
PEMANFAATAN LIMBAH BIJI NANGKA MENJADI DODOL DAN KERUPUK
}

\section{Waste Utilization of Seeds Jackfruit as Dodol and Crackers}

\author{
Deny Utomo ${ }^{1)}$, Kholid Murtadlo ${ }^{2)}$, Cahyuni Novia ${ }^{3)}$ \\ Fakultas Pertanian, Universitas Yudharta Pasuruan ${ }^{1)}$ \\ Fakultas Ilmu Sosial Politik, Universitas Yudharta Pasuruan ${ }^{2)}$ \\ Sekolah Tinggi Teknologi Nurul Jadid Probolinggo ${ }^{3)}$ \\ email : denyut369@gmail.com
}

\begin{abstract}
Utilization of waste processed jackfruit seeds into crackers and dodol an alternative slah one new food rich in nutrients. The research objective knowledge partners want to know about diversifying processed jackfruit seeds. The method of implementation to training and data collection is done by interviews and questionnaires at audience training of both partners. Training results showed that all the partners to make crackers and dodol waste jackfruit seeds and can perform with good packaging and products can be developed.
\end{abstract}

Keywords: jackfruit seeds, crackers, dodol

\begin{abstract}
ABSTRAK
Pemanfaata limbah biji nangka menjadi kerupuk dan dodol merupakan salah satu altenatif makanan baru yang kaya akan nutrisi. Tujuan penelitian ini adalah memberikan pengetahuan kepada mitra mengenai diversifikasi olahan biji nangka. Metode yang digunakan dalam pelaksanaan ini adalah pelatihan dan pengumpulan data dilakukan dengan wawancara dan kuesioner pada pada kedua mitra. Hasil secara keseluruhan mitra kerja dapat membuat kerupuk dan dodol mangga serta dapat melakukan pengemasan dengan baik dan produk dapat dikembangkan.
\end{abstract}

Kata kunci: biji nangka, kerupuk, dodol

\section{PENDAHULUAN}

Masyarakat Desa Bonangan, khususnya para pemuda yang telah putus sekolah banyak yang mengikuti aktifitas pengajian Irsyadul Ibaad yang dibina oleh ustad Agus Budiono. Jamaah pengajian yang berbasis NU (Nahdlatul Ulama) saat ini berjumlah sekitar 20 orang pemuda dengan latar belakang pendidikan yang berbeda-beda dan rata-rata tidak mempunyai pekerjaan alias pengangguran. Selain pengajian, aktifitas kegiatan jamaah ini adalah mendirikan usaha dengan memanfaatkan limbah biji nangka dari beberapa UKM keripik buah untuk dimanfaatkan menjadi kerupuk.
Biji nangka memiliki kandungan gizi yang tinggi seperti karbohidrat, dan protein, sehingga dapat dimanfaatkan sebagai bahan pangan yang potensial. Biji nangka merupakan sumber mineral yang baik. Selain dapat dimakan dalam bentuk utuh, biji nangka dapat diolah menjadi keripik yang enak dan bergizi (Astawan, 2007). Biji buah nangka kaya gizi, terutama kandungan karbohidrat, potassium/kalium, fosfor, dan lemak. Kandungan energi (165 kcal) dan karbohidrat (36,7 kcal) biji nangka yang cukup tinggi dibandingkan dengan kandungan yang sama dari nangka muda dan nangka matang membuat biji nangka menjadi pilihan bagi masyarakat di Asia Selatan untuk menjadikan biji nangka 
sebagai salah satu kudapan penangkal rasa lapar. Kandungan minyak biji nangka mencapai 11,39\% (Sindumarta, 2012).

Pengolahan biji nangka menjadi produk makanan merupakan salah satu bentuk usaha memanfaatkan limbah biji nangka sebagai alternative penambah sumber bahan pangan baru. Salah satu cara yang dapat dilakukan adalah dengan memanfaatkan biji nangka menjadi tepung (Rizal et al., 2013). Tepung biji nangka dibuat dengan cara memilih biji nangka yang baik terutama pada teksturnya, lalu mencuci biji nangka di atas air mengalir. Setelah itu biji nangka direbus hingga kulit ari dari biji nangka terkelupas. Lalu biji nangka dibersihkan, dan dipotong - potong atau diris tipis - tipis. Selanjutnya biji nangka dipotong potong kecil lalu dijemur di bawah terik matahari setelah kering biji nangka digiling (diselip) hingga halus (Nuriana, 2010). Pemanfaatan tepung biji nangka dapat digunakan sebagai bahan pengolahan pangan lebih lanjut seperti kue kering satu, keripik, dan kerupuk yang berbasis pada bahan tepung - tepungan (Rindit, 2008).

Hasil penelitian menunjukkan bahwa dodol dengan subtitusi tepung biji nangka sebanyak $50 \%$ memiliki perbedaan yang signifikan ke arah lebih baik dibandingkan kontrol pada parameter aroma dan tidak berbeda nyata dengan control pada parameter rasa, warna dan tekstur (Wulandari et al., 2014)

Salah satu permasalahan utama adalah pada Jamaah pengajian Irsyadul Ibaad adalah pembuatan tepung limbah biji nangka masih menggunakan semacam alat sederhana, yaitu penumbuk yang terbuat dari kayu dengan kapasitas sekitar $5 \mathrm{~kg}$ biji nangka yang sudah direbus, serta masih menggunakan tenaga manual manusia untuk menumbuknya. Sehingga hasil dari penumbukan kurang baik. Permasalahan yang lainnya adalah limbah biji nangka yang dihasilkan UD. Olivia Jaya sebesar $20 \%$ atau $300 \mathrm{~kg}$ sekali produksi dalam satu hari, sehingga dalam sebulan limbah yang dihasilkan adalah sebesar 9 ton atau 9000 $\mathrm{kg}$.
Peluang untuk mengembangkan usaha kerupuk dan dodol dari limbah biji nangka ini sebenarnya cukup besar dan tidak perlu kuatir kekurangan tenaga kerja, karena di wilayah Desa Bonangan banyak wanita dan ibu-ibu rumah tangga yang tidak bekerja, laki-laki yang bekerja sebagai buruh tani lepas dan punya banyak waktu luang, sehingga keberadaan kelompok usaha tersebut akan membuka peluang lapangan pekerjaan dan memberdayakan masyarakat sekitar.

\section{METODE PELAKSANAAN}

\section{Rancangan kegiatan}

Rancangan kegiatan ini dilaksanakan mulai dari bulan Januari hingga Juli 2016, yaitu bermula dari persiapan dalam tim pelaksana, mempersiapkan lokasi dan mitra kerja, pelaksanaan praktek pembuatan produk dan peninjauan keberlanjutan kegiatan.

\section{Khalayak Sasaran}

Pemilihan mitra kerja dilihat dari keseriusan dan keaktifan dan keberlanjutan organisasi. Penentuan mitra kerja ini dianggap sangat penting karena menjadi salah satu indikator keberhasilan kegiatan. Subyek yang disurvei adalah UD Olivia Jaya dan Jamaah Pengajian Irsyadul Ibaad dan hasil survei yang meliputi wawancara dan observasi mengarah pada kedua mitra tesebut.

Kondisi ini diperkuat karena kedua mitra ini dianggap aktif dan dapat berinteraksi dengan baik. Hal ini diharapkan agar keberlanjutannya adalah dapat mentransfer ketrampilan yang didapatkan saat kegiatan pada kelompok yang lain.

\section{Bahan dan alat}

Bahan krupuk meliputi, limbah biji nangka, tepung tapioka, air, garam, bawang putih, dan gula. Bahan dodol meliputi, limbah biji nangka, santan, gula, natrium metabisulfit, garam, margarine, dan tepung ketan. Alat yang digunakan blender, mesin 
pemarut kelapa, mesin pemotong kerupuk, pisau, timbangan, sutil, bak penampungan bahan, wajan sealer, dandang, kompor, pisau, sendok pengaduk, nampan cetakan, sepet, dan plastik kemasan.

\section{Teknik pengumpulan data dan analisis data}

Pengumpulan data dilakukan dengan melakukan wawancara dan pengisian kuisioner oleh UD Olivia Jaya dan Jamaah Pengajian Irsyadul Ibaad. Pengumpulan data ini dimaksudkan untuk mengetahui status sosial, pendidikan dan motivasi mitra kerja dalam kegiatan IbM yang dilaksanakan agar target luaran dapat tercapai.

\section{HASIL DAN PEMBAHASAN}

Hasil pelaksanaan kegiatan Pengabdian kepada masyarakat melibatkan dua mitra. Mitra kerja yang ikut dalam kegiatan pelatihan pembuatan produksi dan pengemasan adalah 40 peserta dengan latar belakang pendididkan 12 orang SMU, 10 orang SMP dan 18 orang SD. Secara umum, pendidikan mitra kerja mayoritas berlatar belakang tamat SD dan data yang ditemui menunjukkan bahwa tidak ada seorang pun dari peserta yang pernah mengetahui cara pembuatan kerupuk dan dodol.

Rendahnya pengetahuan mengenai limbah biji nangka merupakan fenomena yang menarik perhatian tim kerja untuk melatih dan mentransfer pengetahuan pembuatan kerupuk dan dodol dari limbah biji nangka. Tabel 1 memperlihatkan jumlah mitra kerja yang pernah membuat kerupuk dan dodol dari limbah biji nangka sebelum kegiatan IbM dilaksanakan.

Peserta pelatihan dari kedua mitra berjumlah 40 orang belum pernah membuat kerupuk dan dodol (Tabel 1). Setelah melaksanakan kegiatan, ternyata $100 \%$ mitra kerja dapat membuat produk kerupuk dan dodol dengan baik yaitu secara fisik dan rasa kerupuk dan dodol menarik sehingga dapat dikembangkan sebagai produk yang dapat memberikan alternatif (Tabel 2). Kondisi produk akan lebih menarik dan ketahanan produk meningkat dengan dilakukan pengolahan dan pengemasan yang benar.

Peralatan pengemasan yang dimiliki mitra kerja menjadi modal penting dalam pengembangan produk dan peningkatan nilai jual kerupuk dan dodol. Produk kerupuk dan dodol juga relatif mudah di buat oleh mitra kerja pada saat pelatihan produksi (Tabel 3) dan saat peninjauan keberlanjutan kegiatan. Saat membuat kerupuk dan dodol, tim pelaksana memberikan alternatif dan penjelasan yang mendasar serta sederhana. Penjelasan tersebut berkaitan dengan mitra kerja yang akan mengkonsumsi produk yang dibuat.

Tabel 1. Mitra kerja yang pernah membuat kerupuk dan dodol dari limbah biji nangka sebelum kegiatan IbM

\begin{tabular}{lcc}
\hline & Kerupuk & Dodol \\
\hline Pernah & 0 & 0 \\
Belum pernah & 40 & 40 \\
Jumlah & 40 & 40 \\
\hline
\end{tabular}

Tabel 2. Produk bernilai jual dan dapat dikembangkan

\begin{tabular}{lcc}
\hline & Kerupuk & Dodol \\
\hline Ya & 40 & 30 \\
Tidak & 0 & 10 \\
Jumlah & 40 & 40 \\
\hline
\end{tabular}


Tabel 3. Bahan baku mudah diperoleh dan cara pembuatan produk mudah Kerupuk Dodol

\begin{tabular}{lrc}
\hline Ya & 40 & 40 \\
Tidak & 0 & 0 \\
Jumlah & 40 & 40 \\
\hline
\end{tabular}

\section{KESIMPULAN}

Kesimpulan dari tahapan kegiatan pengabdian kepada masyarakat yang telah dilakukan dapat disimpulkan bahwa:

1. Seluruh mitra kerja dapat membuat kerupuk dan dodol limbah biji nangka serta melakukan pengemasan dengan baik.

2. Produk kerupuk dan dodol limbah biji nangka yang dihasilkan pada pelatihan produksi menarik dan dapat dikembangkan.

\section{DAFTAR PUSTAKA}

Astawan, M. 2007. Tetap Sehat dengan Produk Makanan Olahan. Tiga Serangkai. Surakarta.

Kusumawati, D.D., Amanto, B.S. \& Muhammad, D.R. 2012. Pengaruh perlakuan pendahuluan dan suhu pengeringan terhadap sifat fisik, kimia, dan sensori tepung biji nangka (Artocarpus heterophyllus). Jurnal Teknosains Pangan 1(1).

Qomari, F. 2013. Pengaruh substitusi tepung biji nangka terhadap sifat organoleptik dan sifat kimia kerupuk. Jurnal Tata Boga, 2(1).

Restu, N., Damiati, M.K. \& Ekayani, I.A.P. H. 2015. Pemanfaatan Tepung Biji Nangka Menjadi Kue Pia Kering. Bosaparis 3(1).

Rizal, S., Surmarlan, S.H. \& Yulianingsih, R. 2013. Pengaruh konsentrasi natrium bisulfit dan suhu pengeringan terhadap sifat fisik-kimia tepung biji nangka (Artocarpus heterophyllus). Jurnal Bioproses Komoditas Tropis 1(2): 1-10.

Santoso, M.T., Hidayati, L. \& Sudjarwati, R. 2015. Pengaruh perlakuan pembuatan tepung biji nangka terhadap kualitas cookies lidah kucing tepung biji nangka. Teknologi Kejuruan, 37(2).

Sindumarta, D. 2012. Awet Muda dengan Durian dan Buah-buahan Khas Nusantara. Yogyakarta: Grafindo Litera Media.

Utomo, D., Wahyuni, R. \& Novia, C. 2014. Diversifikasi produk olahan apel manalagi kualitas afkir menjadi selai dan dodol. Jurnal Teknologi Pangan 7 (1).

Wahyuni, R. Utomo, D., Novia, C. dan Syaiful. 2014. Peningkatan nilai ekonomis wortel kualitas afkir menjadi krupuk dan dodol. Universitas Yudharta Pasuruan

Wulandari, R., Ishartani, D., \& Anandito, R. B. K. 2014. Characteristic and the damage during storage in dodol manufacture. Jurnal Teknosains Pangan 3(4): 8-25 